\title{
良導絡診断と漢方の「証」について
}

\section{東京都杉田好 朝}

\section{〔緒 言)}

演者は、西洋医学に漢方と良導絡治療の長所 を併用しているが、漢方と良導絡治療は共に患 者の「異常なバランスの歪み」を診断し、対応 する漢方方剤または適切な体表刺激により、歪 みを正して健康回復を計る治療法である。

この歪みの状態を、良導絡治療では科学的に 診断し、漢方治療では望・聞・問・切の四診を 基に現代的検查法も取りいれて、「証」の診断を 行ない、共に「隋証治療」がなされている。

漢方医学では「方証相対」並びに「証の細分 類により的確な方剤を選出できる」とされてい るので, 演者は、数年前から漢方製剤の帰経・ 八綱・気血水・燥湿・升降について「証」分類 を行い、その結果を各疾患・病証別治療代表方 剤に適用して「証」との関連を検討した結果、 漢方治療ではそれぞれ特有の臓腑経絡に作用す る漢方製剤が使用され、各方剂特有の性能が疾 患・病証に適応して選択されている事実を客観 的に認めた。

次いで、漢方製剤の「証」分類の結果を各症 候別治療代表方剂に適用して、症候別治療方剂 と「証」の関連について検討し、さらに良導絡 診断と方剂の「証」との関連についても検討し たので報告する。

\section{〔方法と結果〕}

方法として、まず医療用漢方製剤 135 製品を 構成している生薬 116 について、日中の漢方医 学書を基に表例（表一1）のような製剤の組成 生薬の「証」分類表を作成した。

$$
\text { これはその一部である。 }
$$

表一1 後掲
この生薬の「証」分類を適用して、表例（表 一2)のように、製剂の組成生薬の数と量から、 各漢方製剤の「証」分類を行なった。

\section{表一2 後掲}

この表のように、縦軸にそれぞれの組成生薬 名と大人一日分服用量を列挙し、横軸に「証」 の分類をして、前表の分類を基に、対応する○ 印の個所に生薬の量を記入し、৩印と=印の個 所には生薬の量を（）中に記入して、漢方製 剤中の証に対応する組成生薬の数または量が多 い場合○印、対応する組成生薬の数と量共に多 い場合○印、組成生薬のすべてが対応する場合 ○印、広義に対応するあのを含めてすべて対応 する場合*印を付け、○印とは判定されないが それに近い場合つ印で示し綜合判定した。

このようにして、漢方製剤 135 製品の「証」 分類表（表一3）を作成した。それはその一部 である。

\section{表一 3 後掲}

この分類結果を各疾患別・臓腑経絡病証別・ 気血津液病証別の治療代表方剂に適用して、各 疾患並びに病証別の「証」分類の合計成績 (\%) と、表示（表一4）の 135 製剂の総括成績（\%) を比較し、治療方剂と「証」の関連を検討した。

表一 4 後掲

その例を表示（表一5）すると、 表一 5 後掲

(1)婦人科疾患では、心・肝・腎経に著明な上

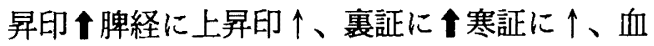
証に、、燥証に个が認められ、

(2)神経症では、心・胃経にヤ心包・脾・肝・

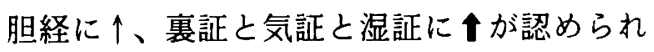
る。 
講演時間の都合で、疾患並び病証別代表方剤 の「証」分類の比較結果を緾めて表示 (表一6) するが、このように、各疾患並びに病証別に特 有の「証」との関連が認められた。

\section{表一 6 後掲}

なお、同様に各症候別治療代表方剂について 「証」分類を検討した。

その例を排尿異常について表示（表一7）す ると、

\section{表一 7 後掲}

(1)多尿・夜間尿では、肝・腎経に、、肺経に

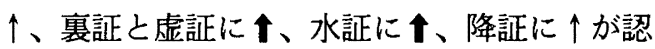
められ、

(2)尿利減少・排尿困難では、心・肝・腎・膀 胱経にヤ小腸経に个、裏証と熱証に、、血証・ 水証に、、湿証と升証に个が認められ、排尿異 常でも両者に相違がみられる。

疼痛については、「証」分類との関連を推察す る観点から、各種疼痛の代表方剂について比較 検討した。

その例を表示（表一8）すると、

表一 8 後掲

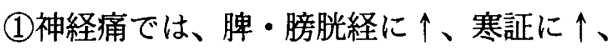
水証に个が認められるが、

(2)腰痛では、心・脾・肝・腎経に、、寒証に

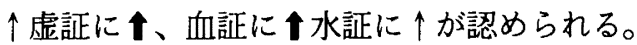

各症候別治療代表方剤について「証」分類の 比較結果を緾めて表示（表一9）する之、

このように、各症候別に特有の「証」との関 連が認められた。

下に良導絡症候群に記載されている痔・脱 肛、糖尿病、てんかんについて付記した。

\section{表一 9 後掲}

以上、漢方製剂の「証」分類を基に各疾患・ 病証並びに症候別治療代表方剂について検討し た結果、それぞれ特有の「証」との関連が認め
られたので、更に良導絡診断特に良導絡症候群 並びに良導絡興奮性のパターンとの関連を検討 中であるが、良導絡診断と漢方の「証」之関連 が認められるので報告する。

良導絡症候群之症候別治療方剤の「証」分類 の関連について表示（表一10）すると、

このように、良導絡症候群と症候別治療方剤 の「証」と一致するものにアンダーラインを付 記したが、症候群の多くが一致し、「証」分類と の関連が認められる。

表一 10 後掲

次いで、良導絡興奮性のパターンと治療方剤 の「証」の関連について表示 (表一11) すると、 同じく良導絡興奮性のパターンの多くが一致 し、「証」分類との関連が認められる。 表一 11 後掲

\section{〔総 括〕}

1）演者は組成生薬の「証」分類を基に、漢 方製剂の八綱・帰経・気血水他「証」分類を行 ない、医療用漢方製剤の「証」分類を一括表示 した。

2）この漢方製剤の「証」分類の結果を各種 の疾患之病証の治療代表方剤に適用し検討した 結果、漢方製剂が疾患並びに病証別の「証」に 相対して選択されている事実を認めることがで きた。

3）今回さらに、各症候別並びに各種の疼痛 別治療代表方剂の「証」分類を検討した結果、 「方証相対」の理論から推察したように、各症候 並びに各種疼痛はそれぞれ特有の「証」と関連 のあることを認めた。

4）なお、良導絡症候群並びに良導絡パター ンと治療漢方方剂の「証」を比較検討した経果、 良導絡診断と漢方の「証」の関連む認めた。 
表一 1

組成生薬の帰経・八綱・気血水他分類表 (1)

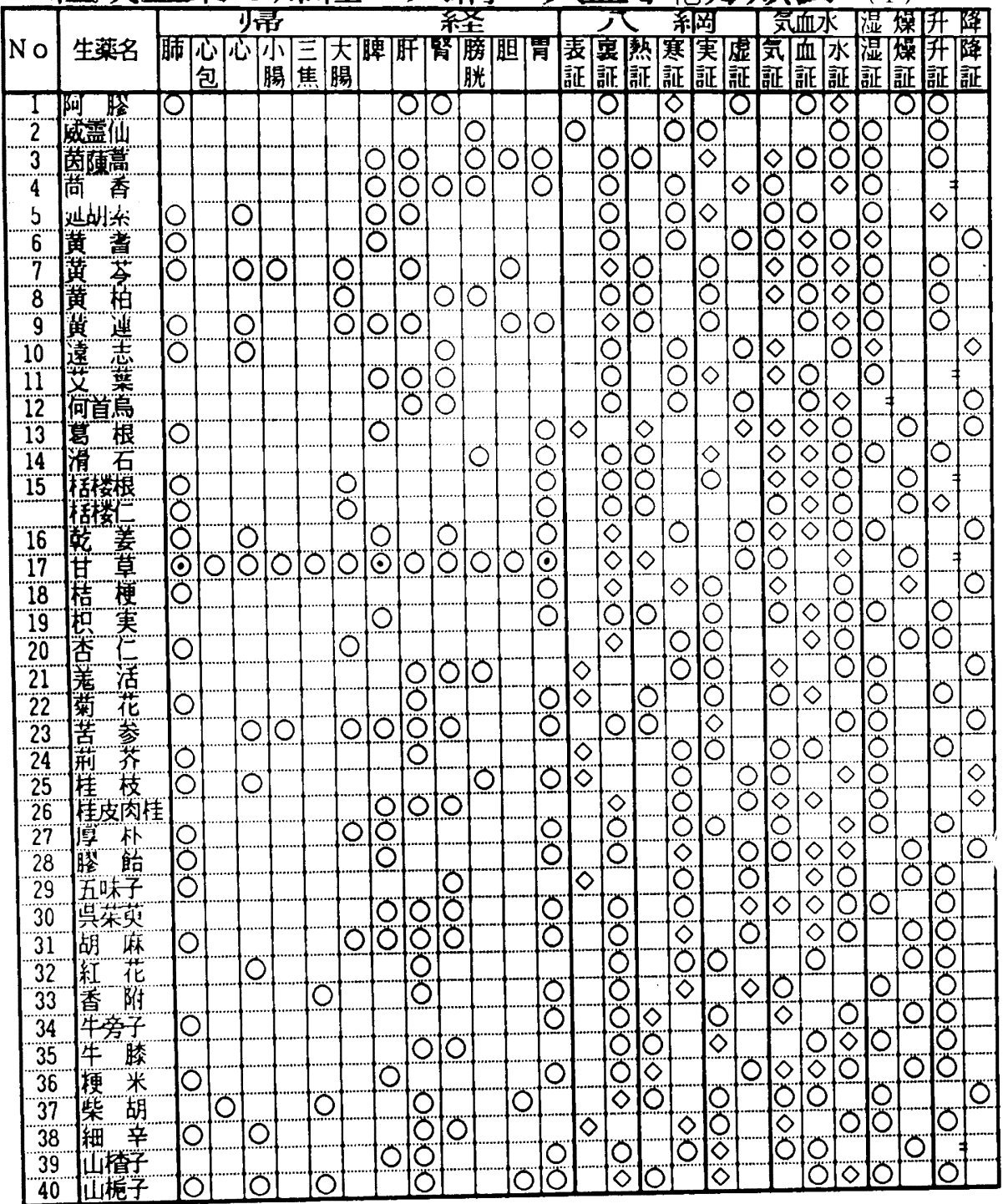

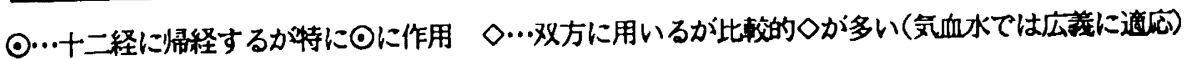


表一2

医療用漢方製荗 No.(16) 半夏厚朴湯

\begin{tabular}{|c|c|c|c|c|c|c|c|c|c|c|c|c|c|c|c|c|c|c|c|c|c|c|c|c|c|c|}
\hline \multirow{3}{*}{$\begin{array}{l}\text { 租 成 } \\
\text { 生录名 }\end{array}$} & \multirow{3}{*}{\begin{tabular}{|l|} 
温合 \\
訶合 \\
$(\mathbf{g})$ \\
\end{tabular}} & \multicolumn{6}{|c|}{4} & \multicolumn{6}{|c|}{ 柽 } & \multicolumn{4}{|c|}{$\lambda$} & \multicolumn{2}{|c|}{ 细 } & \multicolumn{3}{|c|}{ 気 血 水 } & \multicolumn{2}{|c|}{ 温嫌 } & \multicolumn{2}{|c|}{ 开陪 } \\
\hline & & 蜢 & 心包 & 心 & 小心 & 三望 & 大! & 14 & If & $\bar{n}$ & Fitet & 成 & 7 & 表 & 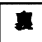 & m & 寒 & 実 & 㡺 & 気 & 血 & 水 & 放 & 媀 & 升 & 整 \\
\hline & & 释 & 程 & 柽 & 释 & 柽 & 柽 & 柽 & 柽 & 柽 & 柽 & 柽 & 柽 & 证 & 噗 & 理 & 通 & 堑 & 証 & 㗏 & 誔 & 㖶 & 噗 & 证 & 鿉 & 拝 \\
\hline 半 & 6 & 6 & & & & & & 6 & & & & & 6 & & 6 & & 6 & & 6 & 6 & & 6 & 6 & & 6 & \\
\hline 获 夻 & 5 & 5 & & 5 & & & & 5 & 5 & 5 & & & 5 & & 5 & (5) & & & 5 & 5 & & 5 & 5 & & 5 & \\
\hline$\sqrt{1 \text { 林 }}$ & 3 & 3 & & & & & 3 & 3 & & & & & 3 & & 3 & & 3 & 3 & & 3 & & (3) & 3 & & 3 & \\
\hline 互 武 & 2 & 2 & & & & & & 2 & & & & & & (2) & & & 2 & 2 & & 2 & & (2) & 2 & & 2 & \\
\hline 生 & 1 & 1 & & & & & & 1 & & & & & 1 & & 1 & & 1 & & 1 & 1 & & (1) & 1 & & & 1 \\
\hline & & & & & & & & & & & & & & & & & & & & & & & & & , & \\
\hline $\begin{array}{r}\text { 数合计 } \\
5 \\
\end{array}$ & & 5 & 0 & 1 & 0 & 0 & 1 & 5 & 1 & 1 & 0 & 0 & 4 & (1) & 4 & (1) & 4 & 2 & 3 & 5 & 0 & $\begin{array}{l}2 \\
\text { (3) }\end{array}$ & 5 & 0 & 4 & 1 \\
\hline & 判 定 & 0 & $x$ & & $x$ & $x$ & & - & & & $x$ & $x$ & 0 & & 0 & & 0 & & & 0 & $x$ & $0^{*}$ & 0 & $x$ & 0 & \\
\hline 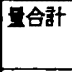 & $17 \mathrm{~g}$ & 17 & 0 & 5 & 0 & 0 & 3 & 17 & 5 & 5 & 0 & 0 & $\sqrt{15}$ & (2) & 15 & (5) & 12 & 5 & 12 & 17 & 0 & $\begin{array}{l}11 \\
(6)\end{array}$ & 17 & 0 & 16 & 1 \\
\hline & 判 定 & 0 & $x$ & & $x$ & $x$ & & 0 & & & $x$ & $x$ & 0 & & 0 & & 0 & & 0 & - & $x$ & 0 & 0 & $x$ & 0 & \\
\hline 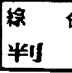 & 定 & 은 & $x$ & & $x$ & $x$ & & - & & & $x$ & $x$ & (๑) & & (๑) & & ๑ & & 0 & - & $x$ & 0 & - & $x$ & (อ) & \\
\hline
\end{tabular}

表一 3

漢方製剂の帰経・八網・気血水他分類表

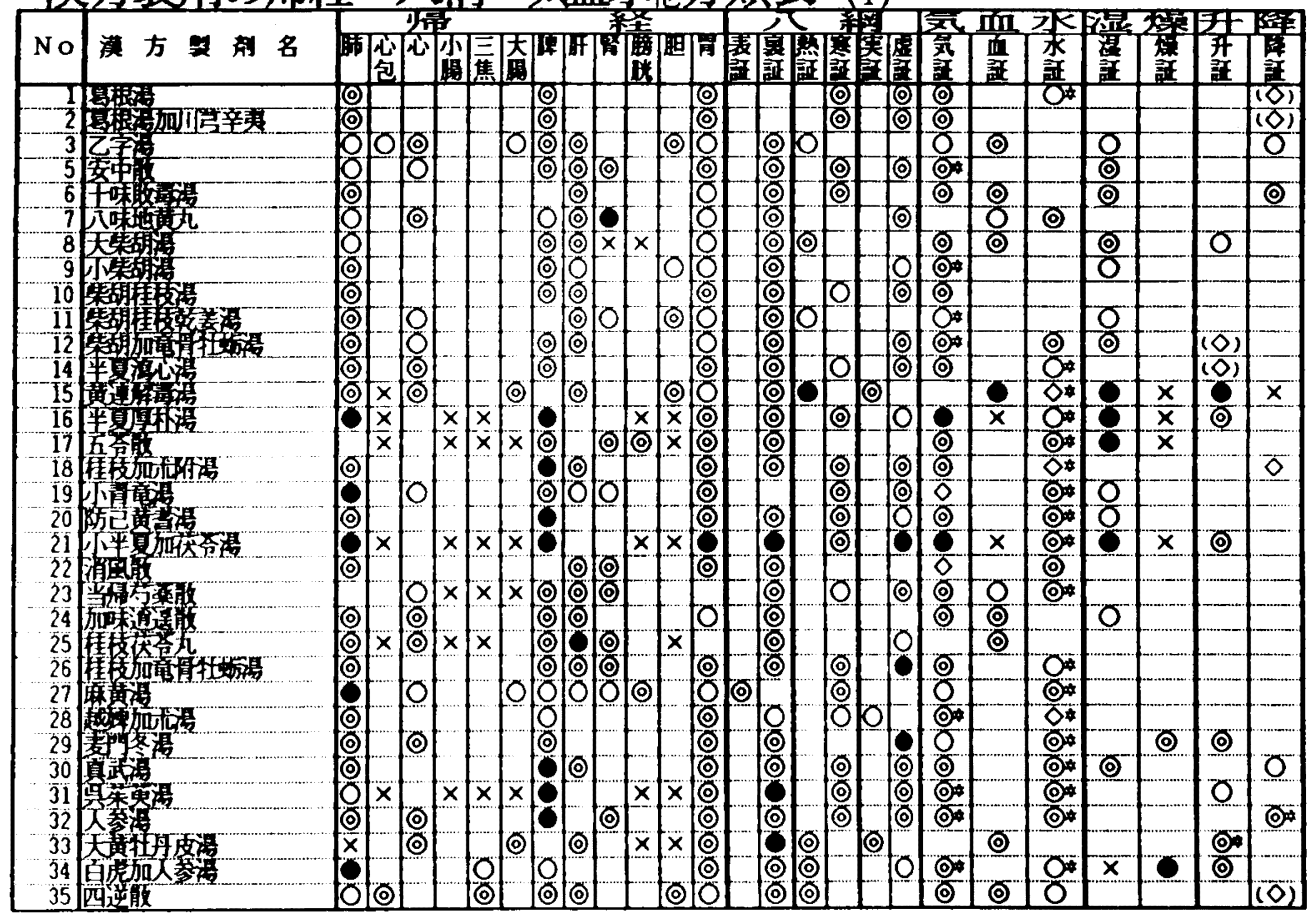


表一 4

漢方製剂の帰経・八網・気血水他「証」分類絰括成㺓表

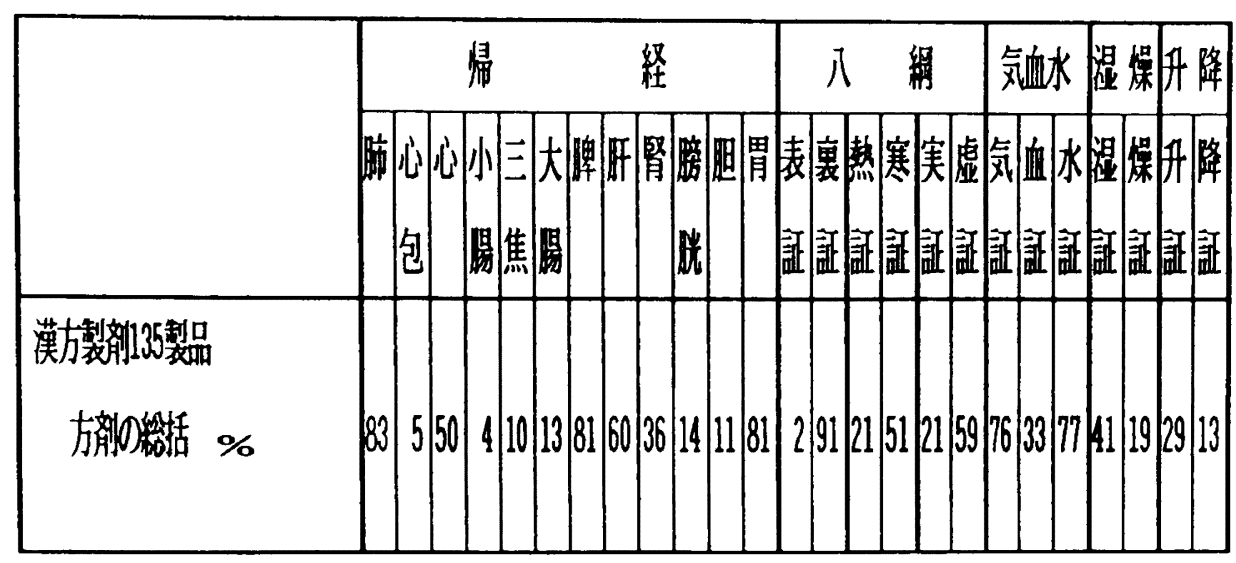

表- 5

婦人科（瘀血・膰異常他）疾患の代表方剂

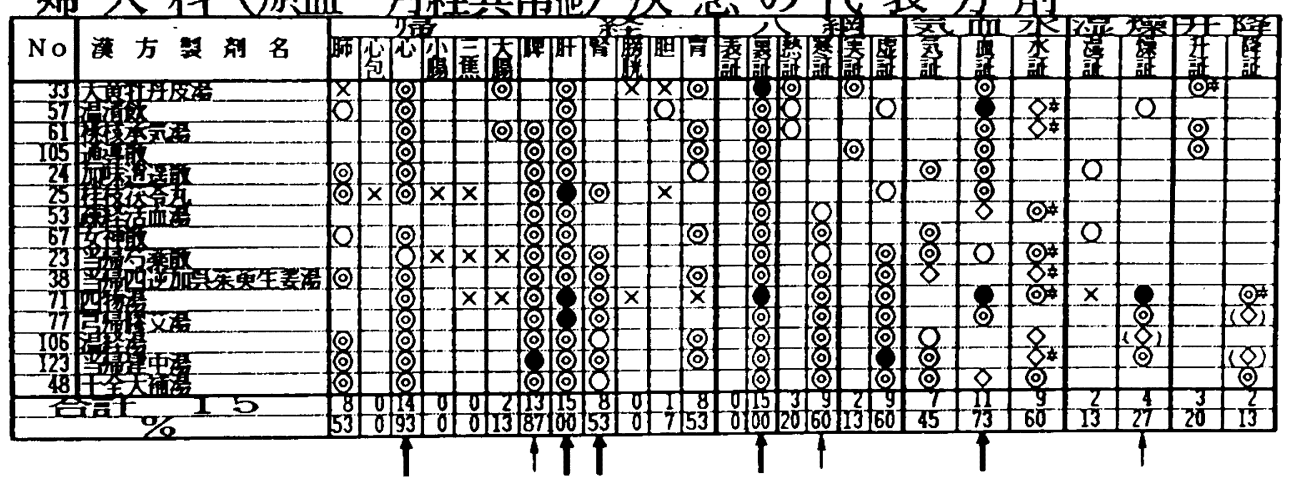

神経症の代表方剂

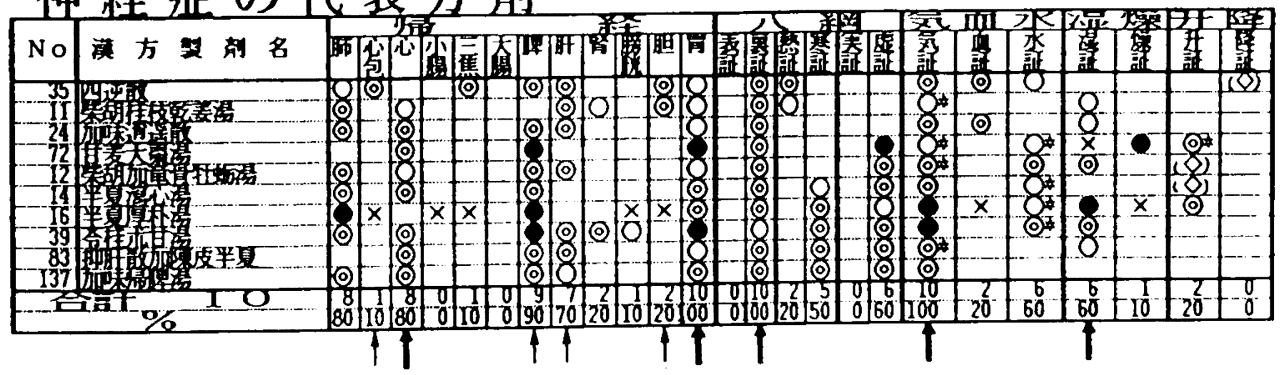


表一 6

疾患並び病証別代表方㓮の㷌経・八網・気血水他分類

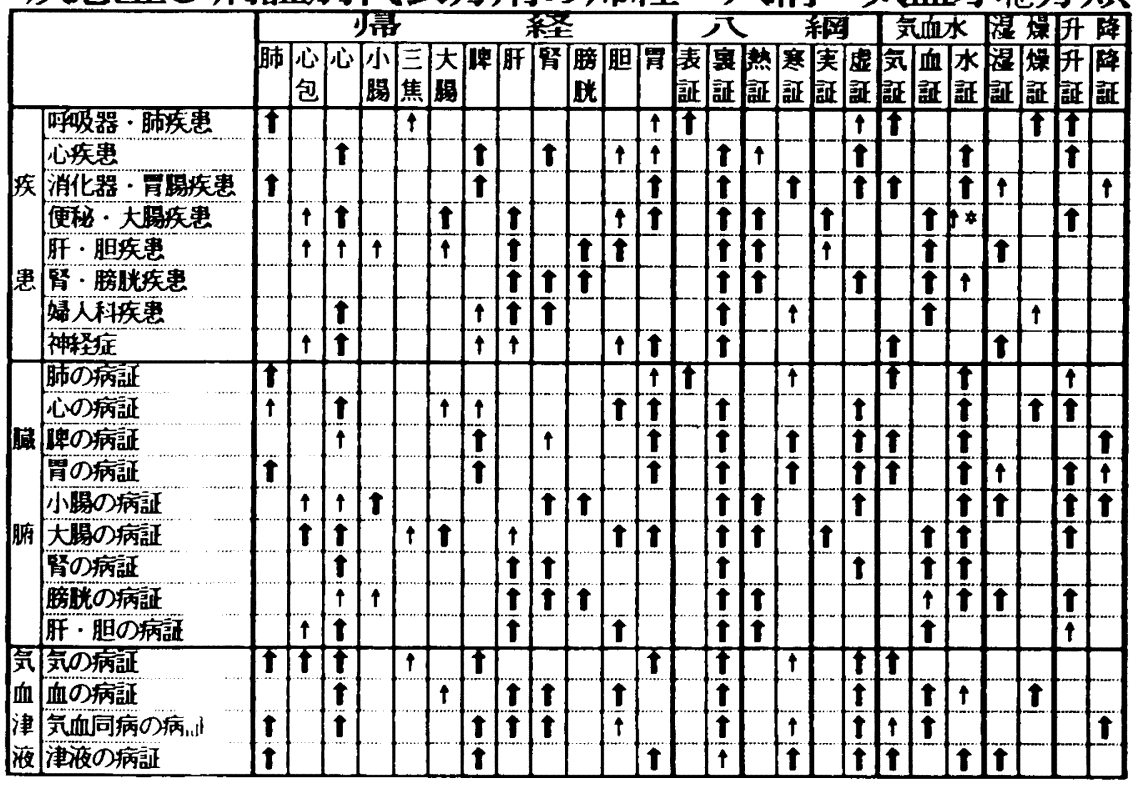

表一7

排尿異掌(多尿・夜間尿) の代 表方 剂

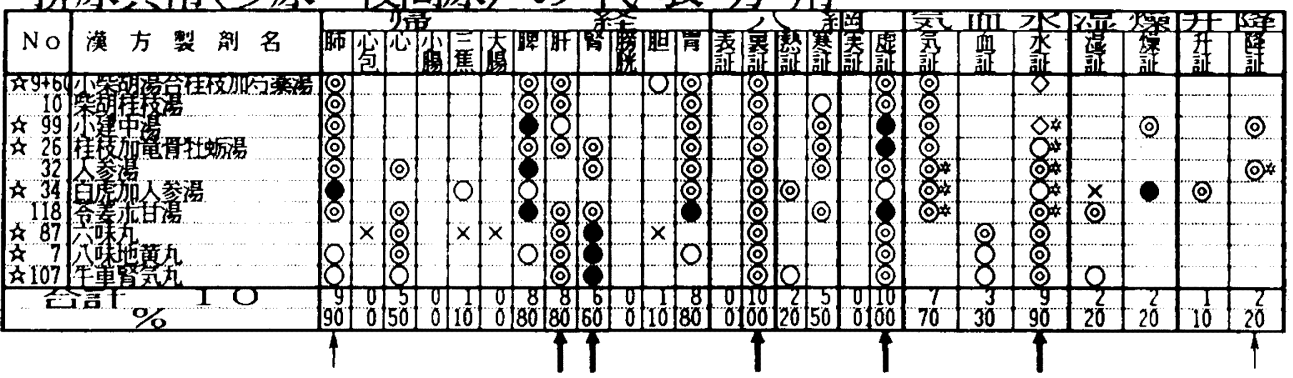

排尿異党(尿利減少・排尿困䧼)の代表方剂

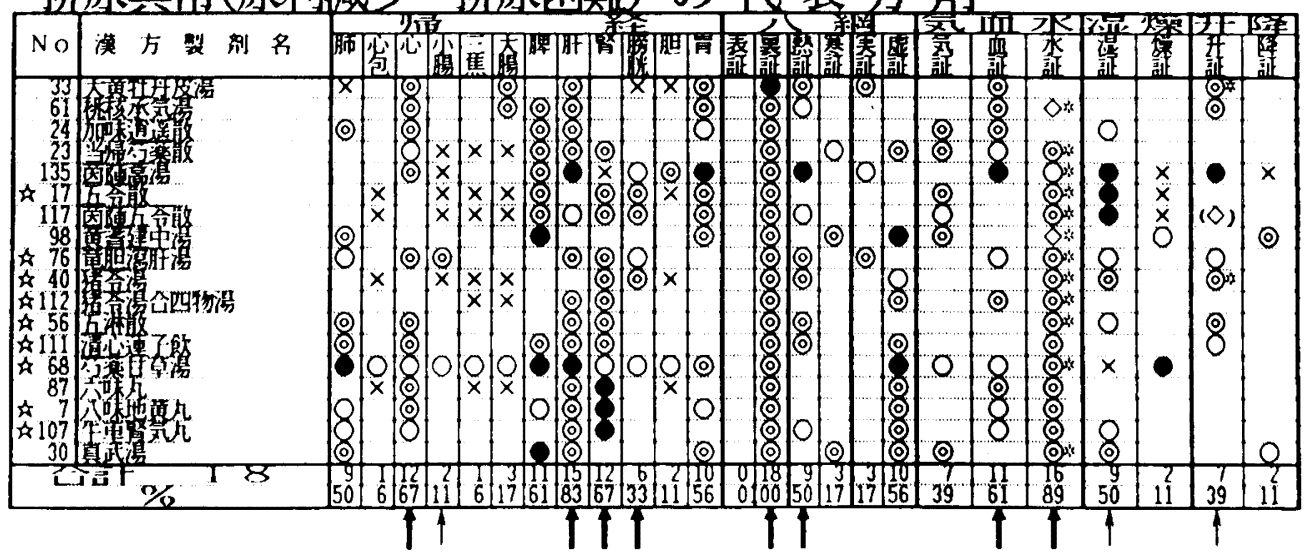


表一 8

神経痛の代表方剂

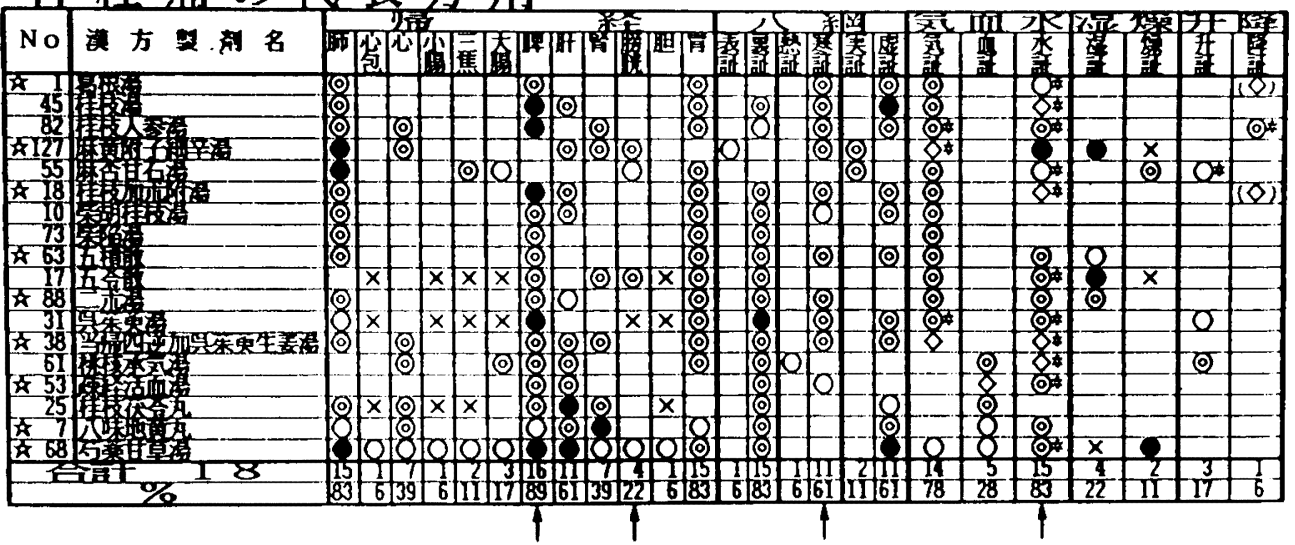

腰痛の代表方剂

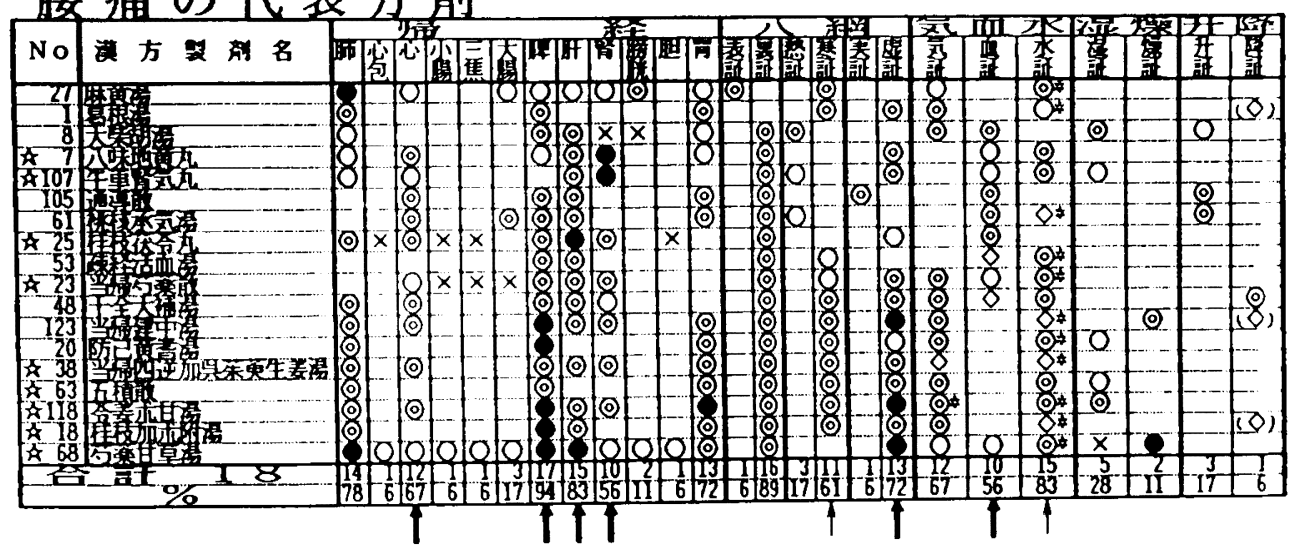

表一 9

症候別代表方凨の帰経・八網・気血水他分類

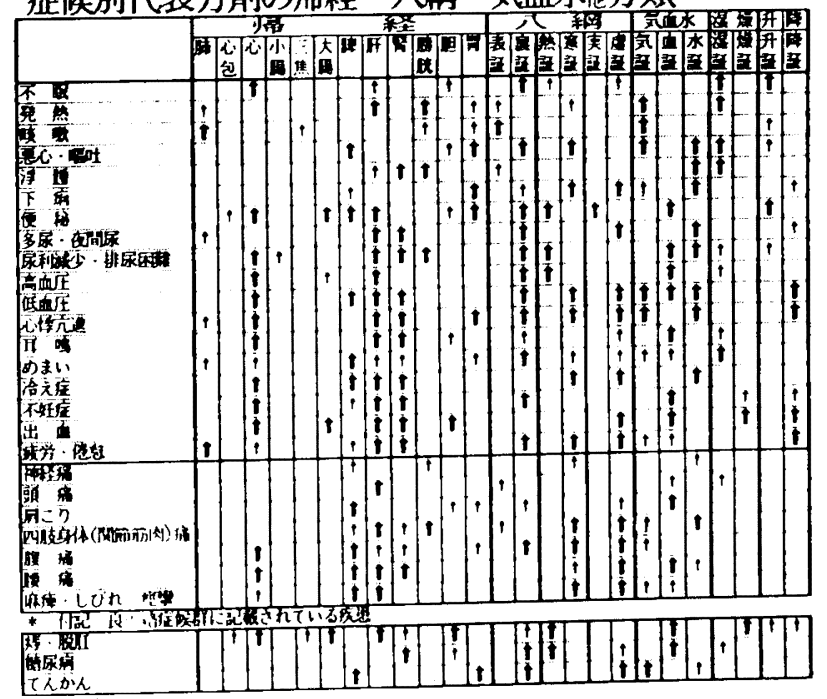


